\title{
СОДЕРЖАНИЕ МЕТАЛЛОВ В КОМПОНЕНТАХ ОКРУЖАЮЩЕЙ СРЕДЫ ГОРНОРУДНОГО РЕГИОНА
}

\author{
И.Н. Семенова, Ю.С. Рафикова, Р.Ф. Хасанова, Г.Р. Ильбулова, \\ М.Б. Суюндукова, Я.Т. Суюндуков \\ Сибайский филиал Государственного автономного научного учреждения \\ «Институт стратегических исследований Республики Башкортостан», г. Сибай, Россия
}

РЕЗЮМЕ. Целью исследования явилось изучение содержания $\mathrm{Cu}, \mathrm{Zn}, \mathrm{Pb}$ и $\mathrm{Cd}$ в компонентах окружающей среды горнорудного региона Республики Башкортостан. Объектами исследования служили пастбищные и пахотные почвы, зерно яровой пшеницы, волосы детей в возрасте до 14 лет. Содержание $\mathrm{Cu}, \mathrm{Zn}, \mathrm{Pb}$ и $\mathrm{Cd}$ в почвах и зерне определяли методом атомной абсорбции, в волосах - методом масс-спектрометрии с индукционно связанной аргоновой плазмой (МС-ИСП) в АНО «Центр биотической медицины» (Москва). Показано, что воздействие горнорудных предприятий на окружающую среду проявляется в повышенном уровне $\mathrm{Cu}, \mathrm{Zn}$ и $\mathrm{Cd}$ в пастбищных почвах, находящихся под их влиянием, а также в более высоком содержании Сu в волосах детей и $\mathrm{Pb}$ и $\mathrm{Cd}$ в зерне пшенице.

КЛЮЧЕВЫЕ СЛОВА: почва, пшеница, волосы, тяжелые металлы, горнорудные предприятия.

\section{CONTENT OF METALS IN THE ENVIRONMENTAL COMPONENTS OF THE MINING REGION}

\author{
I.N. Semenova, Yu.S. Rafikova, R.F. Khasanova, G.R. Ilbulova, \\ M.B. Suyundukova, Ya.T. Suyundukov \\ Sibay Branch of the State Autonomous Scientific Institution \\ "Institute for Strategic Studies of the Republic of Bashkortostan", Sibay, Russia
}

ABSTRACT. The aim of the study was to study the content of $\mathrm{Cu}, \mathrm{Zn}, \mathrm{Pb}$ and $\mathrm{Cd}$ in the environmental components of the mining region of the Republic of Bashkortostan. The objects of research were pasture and arable soils, grain of spring wheat, hair of children under the age of 14 years. The content of $\mathrm{Cu}, \mathrm{Zn}, \mathrm{Pb}$ and $\mathrm{Cd}$ in the soils and the grain was determined by atomic absorption, in the hair - by mass spectrometry with inductively coupled argon plasma (ICP-MS) at Center for Biotic Medicine (Moscow). The environmental impact of mining operations is manifested in increased levels of $\mathrm{Cu}, \mathrm{Zn}$ and $\mathrm{Cd}$ in the grazing soils under their influence, as well as higher levels of $\mathrm{Cu}$ in the hair of children and $\mathrm{Pb}$ and $\mathrm{Cd}$ in wheat grain.

KEYWORDS: soil, wheat, hair, heavy metals, mining enterprises.

\section{ВВЕДЕНИЕ}

Горнорудные предприятия представляют собой комплексный источник воздействия на все компоненты окружающей среды, характеризующийся разнообразием способов этого воздействия и состава загрязняющих веществ. Цель данного исследования - изучение содержания $\mathrm{Cu}, \mathrm{Zn}, \mathrm{Pb}$ и $\mathrm{Cd}$ в компонентах окружающей среды горнорудного региона Республики Башкортостан (РБ) в районах с разным уровнем техногенного воздействия.

\section{МАТЕРИАЛЫ И МЕТОДЫ}

Объектами исследования явились пастбищные и пахотные почвы, зерно яровой пшеницы, волосы детей в возрасте до 14 лет. В образцах почв и зерна в соответствии с СанПин 2.1.7.1287-03 методом атомноабсорбционной спектрометрии определяли содержание тяжелых металлов. Элементный анализ волос проводили в АНО «Центр биотической медицины» (Москва, Россия) (ISO 9001:2008 сертификат 54Q10077 от 21.05.2010).

\section{РЕЗУЛЬТАТЫ И ОБСУЖДЕНИЕ}

Полученные результаты (таблица) сравнивали с референтными значениями (Скальный, 2003). Отмечено превышение ПДК $\mathrm{Cu}, \mathrm{Zn}$ и $\mathrm{Cd}$ в пастбищных почвах, $\mathrm{Pb}$ и $\mathrm{Cd}$ - в зерне пшенице из 2-й группы. 
Таблица. Содержание металлов в компонентах окружающей среды горнорудного региона РБ, мг/кг

\begin{tabular}{|c|c|c|c|c|}
\hline Металл & Субстрат & $\begin{array}{c}\text { ПДК }{ }^{1} / \text { ОДК }{ }^{2} / \\
\text { peференсные значения }^{3}\end{array}$ & $\begin{array}{c}\text { 1-я группа } \\
\text { (Техногенная зона: Баймакский, } \\
\text { Хайбуллинский, Учалинский } \\
\text { и Белорецкий районы) }\end{array}$ & $\begin{array}{c}\text { 2-я группа } \\
\text { (Фоновые территории: } \\
\text { Абзелиловский, Бурзянский, } \\
\text { Зианчуринский } \\
\text { и Зилаирский районы) }\end{array}$ \\
\hline \multirow{4}{*}{$\mathrm{Cu}$} & Почва пастбищная & $55^{1}$ & $80,88 \pm 52,49 *$ & $31,63 \pm 23,76$ \\
\hline & Почва пахотная & $55^{1}$ & $7,99 \pm 2,26$ & $7,11 \pm 1,73$ \\
\hline & Пшеница яровая & $10^{1}$ & $4,74 \pm 1,44$ & $4,63 \pm 0,49$ \\
\hline & Волосы детей & $9-14^{3}$ & $10,53 \pm 0,82^{*}$ & $9,18 \pm 0,35$ \\
\hline \multirow{4}{*}{$\mathrm{Zn}$} & Почва пастбищная & $100^{1}$ & $223,41 \pm 156,65^{*}$ & $62,95 \pm 50,25$ \\
\hline & Почва пахотная & $100^{1}$ & $8,93 \pm 2,86$ & $8,73 \pm 2,42$ \\
\hline & Пшеница яровая & $50^{1}$ & $30,70 \pm 24,99$ & $48,63 \pm 28,11$ \\
\hline & Волосы детей & $155-206^{3}$ & $191,16 \pm 44,13$ & $195,76 \pm 19,11$ \\
\hline \multirow{4}{*}{$\mathrm{Pb}$} & Почва пастбищная & $32^{1}$ & $28,74 \pm 16,07$ & $15,13 \pm 7,03$ \\
\hline & Почва пахотная & $32^{1}$ & $5,98 \pm 0,79$ & $4,60 \pm 2,0$ \\
\hline & Пшеница яровая & $0,5^{1}$ & $0,29 \pm 0,09$ & $1,55 \pm 2,64$ \\
\hline & Волосы детей & $0,38-1,4^{3}$ & $0,97 \pm 0,28$ & $1,10 \pm 0,78$ \\
\hline \multirow{4}{*}{$\mathrm{Cd}$} & Почва пастбищная & $2,0^{2}$ & $2,9 \pm 0,7 *$ & $1,5 \pm 0,6$ \\
\hline & Почва пахотная & $2,0^{2}$ & $0,27 \pm 0,05$ & $0,25 \pm 0,03$ \\
\hline & Пшеница яровая & $0,1^{1}$ & $0,065 \pm 0,103$ & $0,117 \pm 0,099$ \\
\hline & Волосы детей & $0,02-0,12^{3}$ & $0,06 \pm 0,03$ & $0,06 \pm 0,03$ \\
\hline
\end{tabular}

П р и м е ч а н и е : *-статистически значимое $(p<0,5)$ различие показателей 1 -й и 2-й групп.

Сравнение содержания тяжелых металлов в различных биосубстратах в зависимости от уровня техногенеза выявило некоторые отличия. Так, в районах с развитым промышленным производством (1-я группа) пастбищные почвы имеют достоверно более высокое $(p<0,05)$ содержание $\mathrm{Cu}, \mathrm{Zn}$ и $\mathrm{Cd}$, a волосы детей содержат более высокий уровень $\mathrm{Cu}$ по сравнению со 2-й группой. Выявлена положительная корреляция (при $p<0,05)$ : в пастбищных почвах между содержанием $\mathrm{Cu}$ и $\mathrm{Cd}(r=0,85)$, $\mathrm{Pb}$

$(r=0,72)$, в пахотных почвах между содержанием $\mathrm{Cu}$ и и $\mathrm{Zn}(r=0,87)$, в зерне пшеницы и волосах детей между содержанием $\mathrm{Pb}$ и $\mathrm{Cd}(r=0,98$ и $r=0,86$ соответственно).

\section{ВЫВОДЫ}

Воздействие горнорудных предприятий на окружающую среду проявляется в повышенном уровне $\mathrm{Cu}$, $\mathrm{Zn}$ и $\mathrm{Cd}$ в пастбищных почвах, находящихся под их влиянием, а также в более высоком уровне $\mathrm{Cu}$ в волосах детей. Вместе с тем в пшенице яровой, выращенной в районах с отсутствием выраженного техногенного воздействия, также выявлен повышенный уровень $\mathrm{Cd}$ и $\mathrm{Pb}$, что, вероятно, обусловлено региональными геохимическими особенностями.

Работа подготовлена за счет финансового обеспечения выполнения государственного задания ГАНУ «Институт стратегических исследований Республики Башкортостан» на 2021 г. (руководитель темы - Я.Т. Суюндуков).

\section{Список литературы / References}

1. Скальный А.В. Референтные значения концентрации химических элементов в волосах, полученные методом ИСП-АЭС (АНО «Центр биотической медицины»). Микроэлементы в медицине. 2003; 4(1): 7-11 [Skalny A.V. Reference values of chemical elements concentration in hair, obtained by means of -AES method in ANO Centre for Biotic Medicine. Trace Elements in Medicine (Moscow). 2003, 4(1): 55-56 (in Russ)]. 